\title{
PHAGOCYTOSIS OF SPERMATOZOA BY THE EPITHELIAL CELLS OF THE DUCTULI EFFERENTES AFTER EPIDIDYMAL OBSTRUCTION IN THE RAT
}

\author{
ANITA P. HOFFER, D. W. HAMILTON AND D. W. FAWCETT \\ Department of Anatomy, and Laboratory of Human Reproduction and \\ Reproductive Biology, Harvard Medical School, Boston, \\ Massachusetts 02115, U.S.A.
}

(Received 17th Fune 1974)

\begin{abstract}
Summary. The effects of ligation of an isolated loop of the ductus epididymidis in the region of the caput were compared with those of the exfoliative lesion of the epididymis that follows administration of $\alpha$ chlorhydrin to rats. Electron micrographs of the ductuli efferentes in both cases revealed early phagocytosis of apparently normal spermatozoa by the epithelial cells, followed at later intervals by invasion of macrophages and intraluminal phagocytosis. It is concluded that epithelial spermiophagy is a consequence of obstruction, whether mechanically or chemically induced.
\end{abstract}

\section{INTRODUGTION}

In the course of earlier studies on the pathogenesis of the obstructive lesion produced in the initial segment of the rat epididymis by $\alpha$-chlorhydrin (Hoffer, Hamilton \& Fawcett, 1973), it was observed that the non-ciliated cells of the epithelium lining the ductuli efferentes began to phagocytose spermatozoa from the lumen within $48 \mathrm{hr}$ after administration of the drug. Because of the current interest in the sequelae of interruption of the excurrent duct system of the male, we have extended our initial observations (Hoffer \& Hamilton, 1974) in an effort to determine whether this unusual behaviour of the epithelium is a direct effect of $\alpha$-chlorhydrin on the ductuli efferentes or a secondary effect of high obstruction of the ductus epididymidis.

\section{MATERIALS AND METHODS}

The $\alpha$-chlorhydrin (U-5897, Upjohn Co., Kalamazoo, Michigan) was dissolved in $0.25 \%$ methyl cellosolve in distilled water and given to eight adult male rats (CD-Charles River) by stomach tube. A single dose ( $140 \mathrm{mg} / \mathrm{kg}$ ) was given and the rats were killed 2, 4, 7 or 12 days later. Four other rats were anaesthetized with Nembutal 48 or $96 \mathrm{hr}$ before autopsy and a single convolution of the epididymal tubule in the initial segment was ligated with 6-0 surgical 
suture in order to compare the effects of chemically and mechanically induced obstruction of the initial segment.

At the time of autopsy, the animals were anaesthetized with Nembutal and killed by perfusion through the aorta (Vitale-Calpe, Fawcett \& Dym, 1973) with $5 \%$ glutaraldehyde in $0 \cdot 16 \mathrm{~m}$-collidine buffer $(\mathrm{pH} \mathrm{7.4)}$. The testes and epididymides were thus fixed for electron microscopy. After rinsing for 60 min in buffer at $\mathrm{pH} 7 \cdot 25$, the tissue was post-osmicated for $2 \mathrm{hr}$, dehydrated, embedded in Epon, sectioned with a diamond knife and examined with an RCA-EMU-3G electron microscope.

The normal morphology of the ductuli efferentes has been reviewed (Hamilton, 1975) and a detailed description of their ultrastructure need not be repeated here. Briefly, the lining of rat ductuli is a simple columnar epithelium consisting of ciliated and non-ciliated cells. Occasional lymphocytes are also present between the columnar cells. There is nothing remarkable about the ultrastructure of the ciliated cells and there is no evidence that they take up material from the lumen. The luminal surface of the non-ciliated cell has a border of sparse microvilli and between them are numerous vesicular and canalicular invaginations of the plasmalemma which appear to be manifestations of endocytosis (Young, 1933; Mason \& Shaver, 1952; Shaver, 1954; Grant, 1958; Burgos, 1964; Nicander, 1965; Sedar, 1966). Numerous large vacuoles, apparently empty, and multi-vesicular bodies are found deeper in the cytoplasm.

\section{RESULTS}

Within $48 \mathrm{hr}$ of oral administration of a single dose of $\alpha$-chlorhydrin, an obstructive lesion in the initial segment of the epididymis (Pl. 1, Figs 1 and 2) was detectable on gross examination. Because the several efferent ductules emerging from the rat testis fuse distally into a common efferent ductule which is continuous with the epididymal duct (Benoit 1926; Reid \& Cleland, 1957), the lesion in the initial segment of the epididymis resulted in accumulation of fluid and spermatozoa and a rise in hydrostatic pressure in all the efferent ductules. A high concentration of spermatozoa was observed in the lumen of the ductuli proximal to the obstructive lesion, whereas, in control animals, relatively few spermatozoa were observed in the lumen of unobstructed efferent ductules. During the first few days after $\alpha$-chlorhydrin, the majority of spermatozoa impounded in the lumen of the ductuli still appeared normal (PI. 2, Fig. 4), but increasing numbers of degenerating spermatozoa were found later.

Examination of the epithelium of the ductuli as early as $48 \mathrm{hr}$ after administration of the drug revealed the onset of uptake of spermatozoa into the nonciliated cells and this epithelial spermiophagy became increasingly evident after longer intervals. The cells involved were normal in appearance except for the shape of the nucleus which was more irregular than usual. This may simply have been due to mechanical deformation by ingested spermatozoa. The junctional complexes between epithelial cells remained intact and spermatozoa or products of their degeneration were never found in the intercellular 
spaces. There may have been a slight increase in the frequency of mitotic figures, but this was not verified statistically.

All stages in the uptake of spermatozoa by the non-ciliated cells could be readily identified. In the initial contact between the spermatozoon and the microvilli of the absorptive cells, the plasma membranes of both were intact and the acrosome and subacrosomal structures appeared normal (Pl. 2, Fig. 4). The epithelial cell subsequently extended long irregular pseudopodia that engulfed the spermatozoon (Pl. 2, Fig. 5 and Pl. 3, Fig. 6). These processes contained no organelles but seemed to be composed mainly of a filament-rich ectoplasmic layer of the cytoplasmic matrix. Pseudopodia of almost identical appearance were associated with motility and phagocytosis by wandering leucocytes (P. I, Fig. 3) and macrophages, but it was unusual to see such processes on sessile epithelial cells. When the latter took up substances in bulk at their free surface, it was usually by invagination of the surface to form pinocytotic vesicles, rather than by extension of pseudopodia.

The ingested spermatozoa were contained in membrane-limited vacuoles in the apical or perinuclear cytoplasm and their ultrastructure soon after their ingestion appeared normal. The acrosomal content was homogeneous and of normal density and portions of the sperm plasma membrane and outer acrosomal membrane were often still present (Pl. 4, Figs 8 and 9). In other sections, sperm tails of normal appearance were found in the cytoplasm (Pl. 3, Fig. 7). Vacuoles containing phagocytosed sperm heads and tails were at first surrounded by a filament-rich zone of cytoplasm which was comparable in its fine structure to that in the pseudopodia that originally engulfed the spermatozoa (Pl. 3, Fig. 7). This zone of filaments later disappeared.

Spermatozoa in more advanced stages of degradation could be identified in the basal cytoplasm by $48 \mathrm{hr}$ after $\alpha$-chlorhydrin treatment. The number of phagocytosed spermatozoa observed in the epithelial cells after 3 or 4 days was considerably increased and degenerative changes were more advanced. The plasma membrane and acrosome of the sperm heads was seldom present and the nuclear material was ragged at the periphery and irregular in outline (Pl. 4, Fig. 10). Successive phases in the morphological disintegration of the sperm nucleus could be recognized. In the degenerating sperm tails, the microtubular elements of the axonemal complex and the mitochondrial sheath were broken down first (Pl. 4, Fig. 10), while the fibrous sheath and the outer coarse fibres were the most resistant to degradation. The coarse fibres were still more or less intact long after they had lost their characteristic arrangement and could no longer be identified by number. When the degenerate spermatozoa were finally digested, they were sequestered within lysosome-like bodies, or phagosomes, containing myelin figures, amorphous fragments of electrondense material and occasional recognizable remnants of spermatozoa.

A few macrophages containing spermatozoa were observed in the lumen of the ductuli as early as $48 \mathrm{hr}$ after $\alpha$-chlorhydrin administration and their number increased with time. The sequence of morphological events in the breakdown of spermatozoa within the macrophages was basically similar to that in the epithelial cells (Pl. 5, Fig. 12). The intraepithelial macrophages exhibited considerable variation in size, shape and content of phagosomes depending upon 
their age and the duration of their exposure to ingestable material. They could be distinguished from the surrounding epithelial cells by the irregularity of outline conferred by their pseudopodia, by their cytoplasmic characteristics and by the absence of desmosomes joining them to neighbouring cells.

\section{EXPLANATION OF PLATES}

\section{PLATE 1}

FrG. 1. The excurrent duct system of the rat showing the normal ductuli efferentes and initial segment.

Fig. 2. The excurrent duct system of a rat after a high dose of $\alpha$-chlorhydrin, showing the obstructive lesion in the initial segment and the ductuli distended with testicular fluid and spermatozoa.

Fig. 3. A polymorphonuclear leucocyte, a known phagocytic cell, with two blunt pseudopodia consisting of apparently homogeneous ectoplasm free of organelles or inclusions. This micrograph is presented to permit comparison with similar processes on epithelial cells of the ductuli illustrated in later figures.

\section{PLATE 2}

Fra. 4. The microvillous border of an absorptive epithelial cell of a ductulus efferens of a rat $84 \mathrm{hr}$ after receiving $\alpha$-chlorhydrin. Spermatozoa in the lumen appear intact and essentially normal. The edge of a sperm head is held in a shallow groove of the cell surface. This apparently represents an early stage in the attachment phase of phagocytosis.

Fig. 5. The luminal border of a rat epithelial cell showing one sperm head at the left adhering to the surface with a local condensation of the subjacent cytoplasm. At the right, a sperm head is being engulfed by extension of two pseudopodia which are very similar in their fine structure to those of the free phagocytic cell illustrated in Fig. 3.

\section{PLATE 3}

Fic. 6. An additional example of a rat epithelial cell extending pseudopodia around a sperm head.

Frg. 7. A recently phagocytosed sperm tail in the apical cytoplasm of a rat epithelial cell. It is still surrounded by a homogeneous zone of finely filamentous cytoplasm comparable to that of the pseudopodia that form at the cell surface.

\section{PLATE 4}

Fig. 8. A recently phagocytosed sperm head in the juxta-nuclear cytoplasm of an epithelial cell of the excurrent duct of a rat 12 days after $\alpha$-chlorhydrin. The membranes appear to be intact and there has been no digestion of the condensed chromatin.

Fro. 9. A rat sperm head partly or, perhaps, completely within the apical cytoplasm. There has been some slight distortion of the shape of the acrosome but its membrane remains intact and there is, as yet, no evidence of digestion.

Frg. 10. Several phagocytosed rat sperm heads and two sperm tails showing clear evidence of degradation. The microtubules of the flagellar axonemes have disappeared leaving only the more resistant outer dense fibres. The membranes of the sperm heads have disappeared and the highly irregular outline of the nuclei suggests peripheral disintegration and digestion.

\section{PLATE 5}

Fig. 11. A polymorphonuclear leucocyte in the lumen of a ductulus efferens of a rat 12 days after obstruction. It contains a phagocytosed sperm head and some partly digested flagella. It is largely depleted of specific granules.

FIG. 12. A phagocytic wandering cell among the cells of the rat epithelium. It contains a sperm head and several sections of partly digested sperm tails.

\section{PLATE 6}

Fig. 13. Ductuli efferentes of a rat 10 to 12 days after obstruction of the ductus epididymidis, showing the amorphous grey contents in the lumen. This is probably a result of condensation and inspissation of impounded testicular fluid. It may also contain products of intraluminal degradation of spermatozoa and disintegration of phagocytes.

Fig. 14. The amorphous, presumably proteinaceous, material that accumulates in the lumen of the rat ductuli efferentes is taken up by pinocytosis into the non-ciliated cells and can be seen in large vacuoles in their cytoplasm. 
PLATE 1
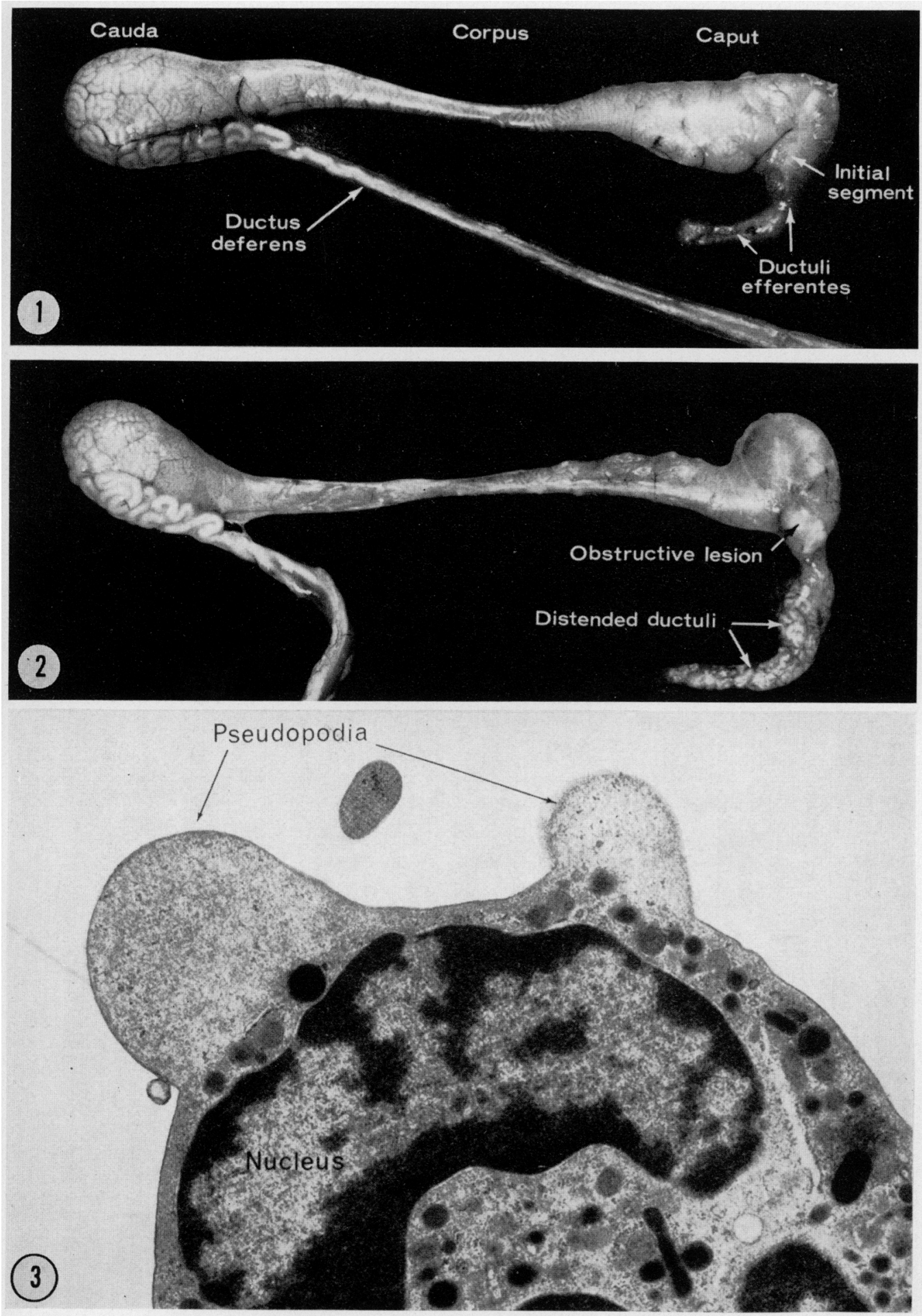

Ficings to 1 , 
$\mathrm{PLATE}, 2$
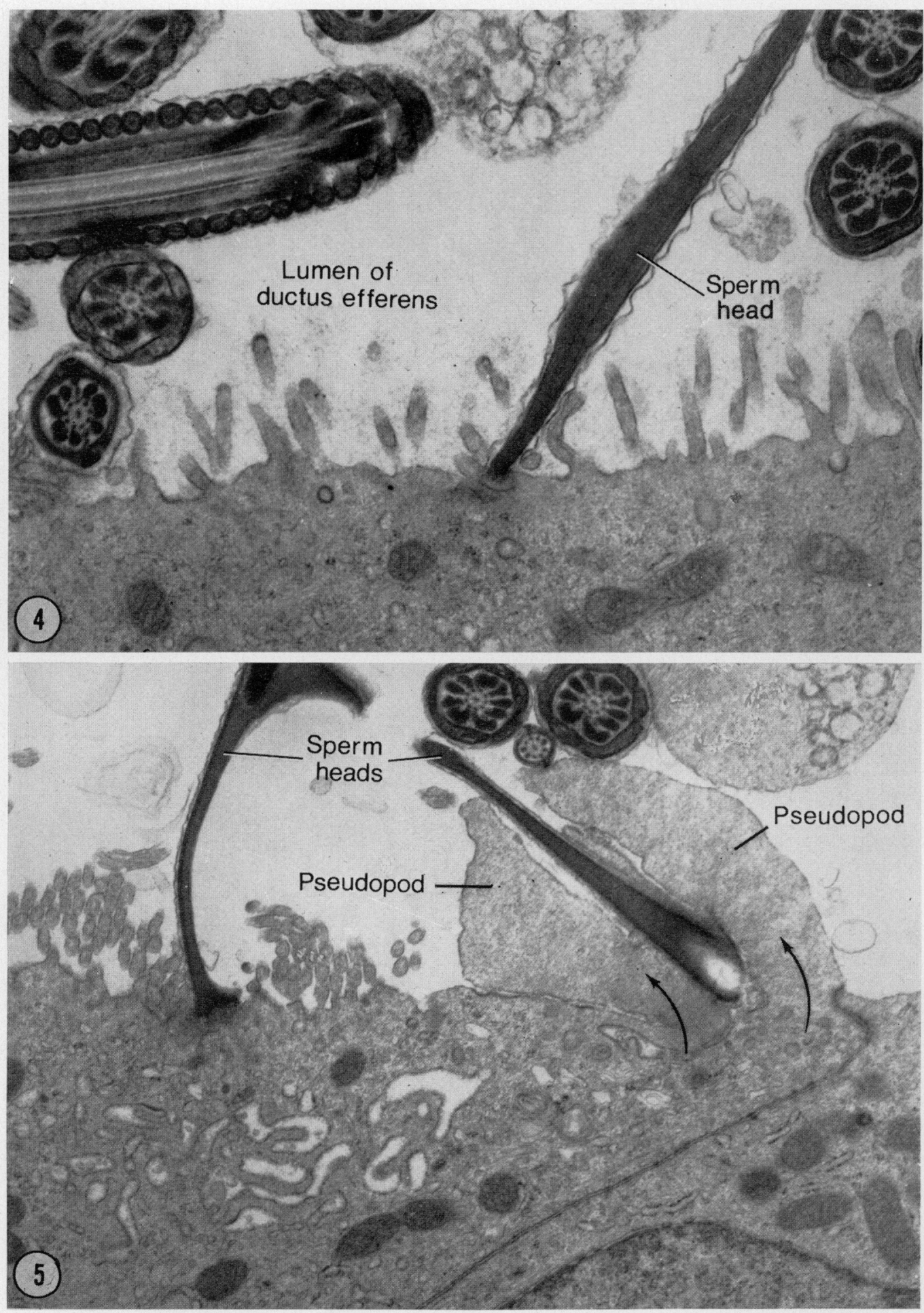

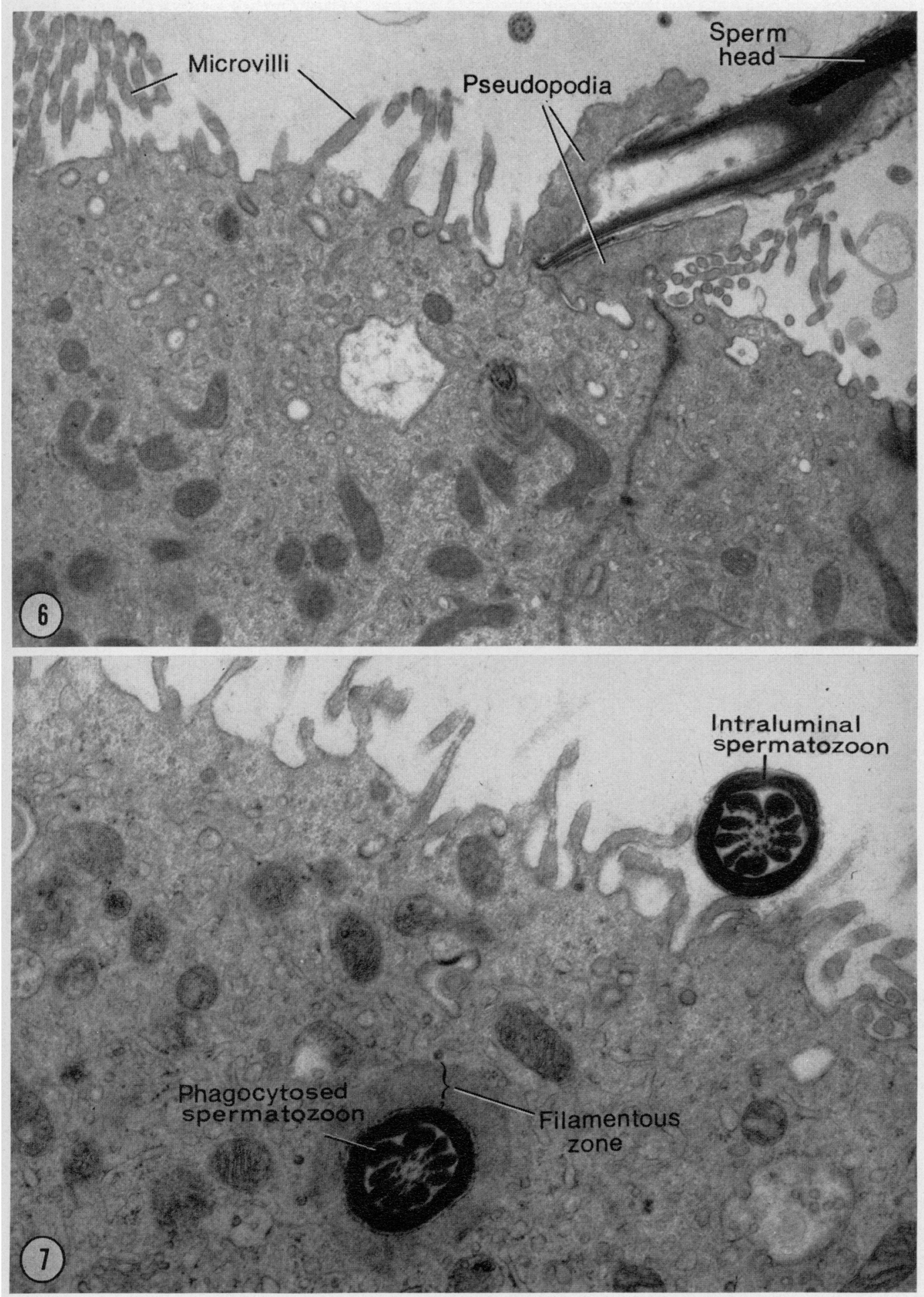
PI.XTl:4
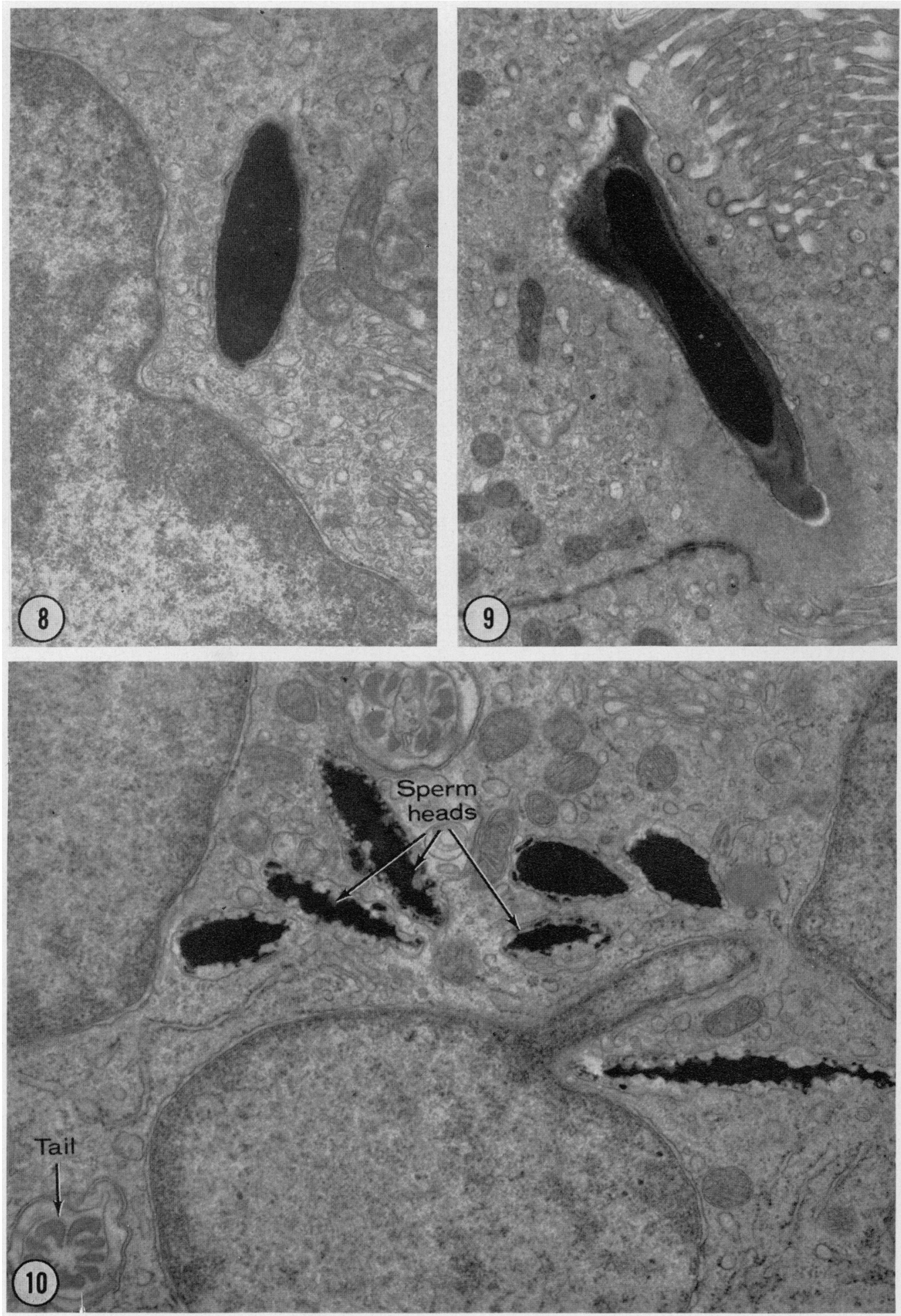


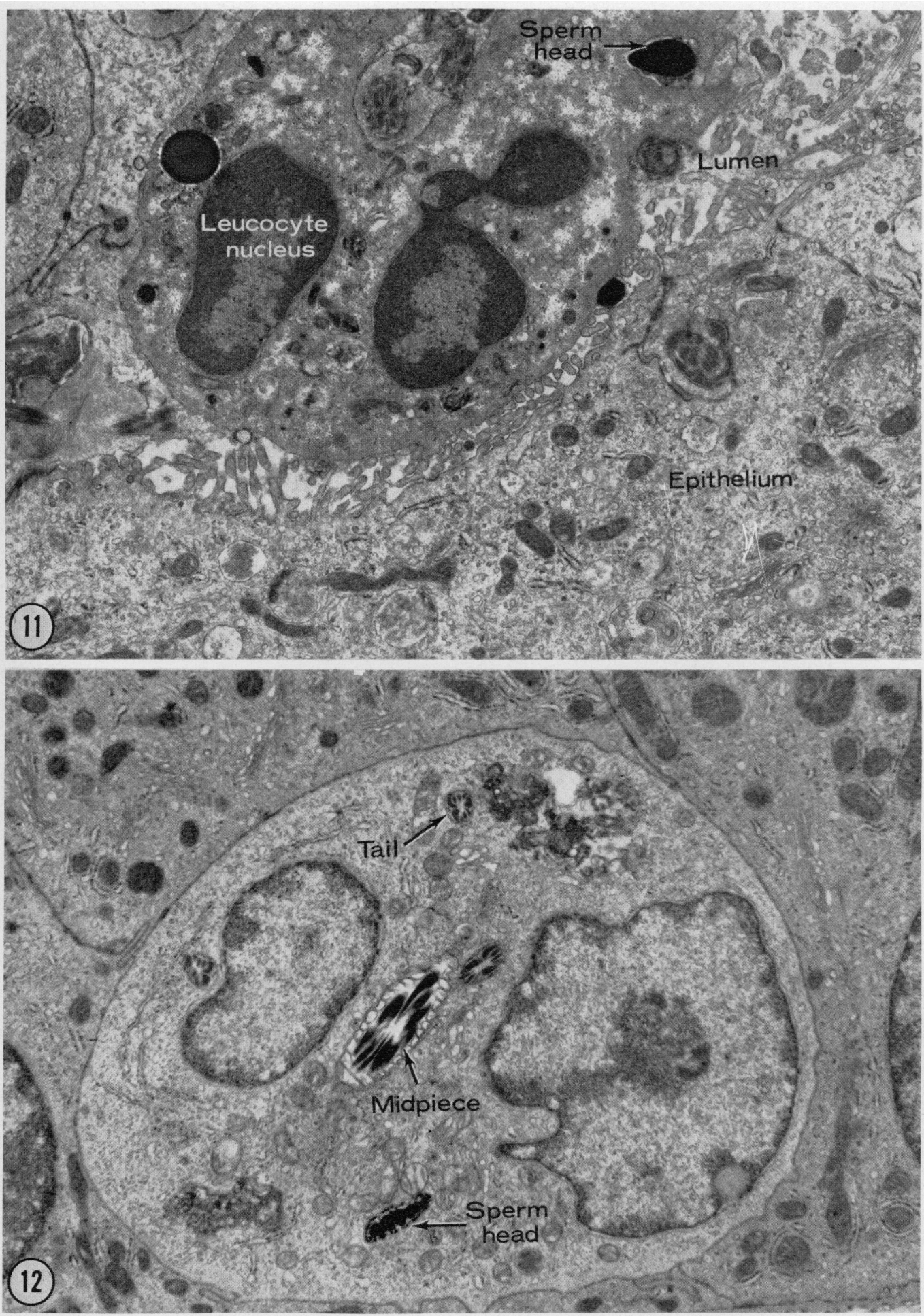



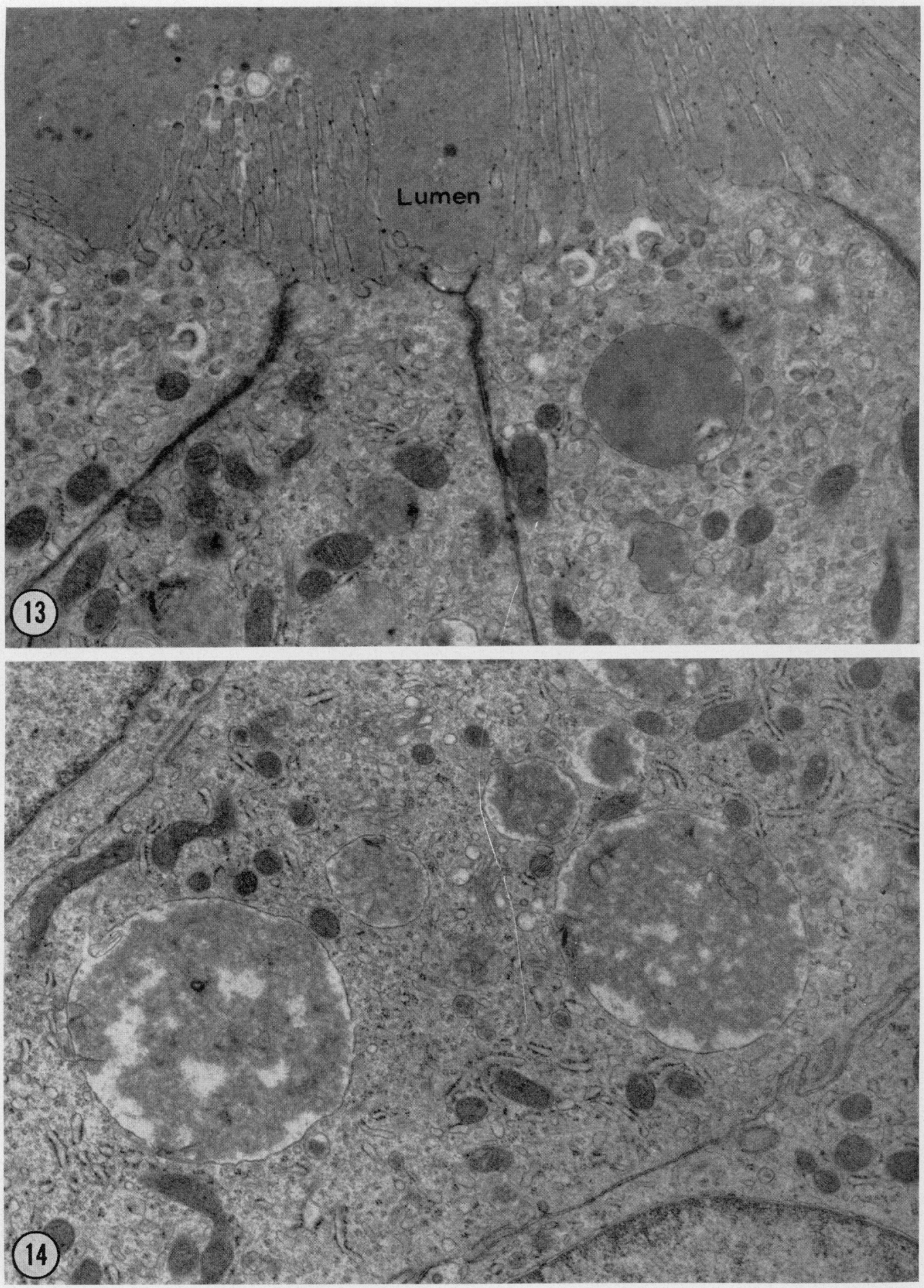

Facing to. : 
Polymorphonuclear leucocytes could also be identified in the epithelium and in the lumen. Leucocytes fixed in the process of ingesting spermatozoa (Pl. 5, Fig. 11) appeared to have fewer granules than those that did not contain spermatozoa. Neither macrophages nor leucocytes containing spermatozoa were ever observed in the peritubular connective tissue.

About 12 days after administration of the drug, a dense flocculent material was observed in the lumen of the ductuli efferentes (PI. 6, Fig. 13). This material was also found in the plasmalemmal invaginations, as well as in apical and supranuclear vacuoles of the absorptive cells (P1. 6, Fig. 14).

In the rats subjected to ligation of the ductus epididymidis, spermiophagy by non-ciliated epithelial cells was consistently observed and was similar in all respects to that in animals receiving the $\alpha$-chlorhydrin. Spermatozoa and sperm fragments were likewise found in neutrophils and macrophages in the epithelium and in the lumen.

\section{DISCUSSION}

The fate of non-ejaculated spermatozoa in sexually inactive, but otherwise normal males is unclear. The presence of spermatozoa in the urine has been demonstrated for several species (Oslund, 1928; Wilhelm \& Seligman, 1937; Koefoed-Johnsen, 1964). It has been estimated that the number of spermatozoa voided in urine each day by the ram approaches $90 \%$ of the daily sperm production (Lino, Braden \& Turnbull, 1967). If this level of loss was common to all mammals, there would be no reason to postulate a significant amount of sperm resorption in the excurrent duct system. In some species, however, there seem to be significant differences between estimated sperm production rates and the sperm output accompanying ejaculation or micturition. This has fostered the belief that substantial numbers of spermatozoa are normally disposed of within the male reproductive tract (Simeone \& Young, 1931; Amann \& Almquist, 1962). It is surprising, however, that the literature contains little morphological evidence to support this view. Phagocytosis by epithelial cells or by macrophages has usually been described in the corpus and cauda epididymidis proximal to a pathologically obstructed or surgically ligated ductus deferens (Nicander, 1963; Phadke, 1964; Flickinger, 1972; Alexander, 1972) rather than in normal animals.

Intraluminal destruction of spermatozoa by macrophages has been reported more frequently than uptake by epithelial cells. Roussel, Stallcup \& Austin (1967) reported that macrophages are normally present in the epididymal lumen in very small numbers and that they exhibit a selective phagocytosis of dead or deteriorating spermatozoa in the corpus and cauda epididymidis of bulls, rabbits and monkeys. The presence of spermiophages in the lumen of the human epididymis has also been reported (Holstein, 1967). There seems to be no doubt that after long-term vasectomy in man and monkey, large numbers of macrophages do enter the lumen and dispose of spermatozoa (Phadke, 1964; Alexander, 1972).

Epithelial spermiophagy in the ductuli efferentes appears to have been 
reported before only in a single subnormal bull (Crabo, Gustafsson, Nicander \& Rao, 1971) and in vasectomized domestic fowl (Tingari \& Lake, 1972). Although distension of the ductuli efferentes and intraluminal phagocytosis is reported after vasectomy in monkeys (Alexander, 1972) and in man (Phadke, 1964), no mention is made of phagocytosis by epithelial cells. In the female, sperm heads have been observed in the epithelium of the oviduct (Austin, 1959; Austin \& Bishop, 1959), but the limited resolution of those light microscopic studies makes it uncertain whether the spermatozoa were within or between the epithelial cells and gives no indication of the mechanisms of sperm uptake.

The present electron microscopic studies clearly demonstrate that the nonciliated cells of the ductuli efferentes can be stimulated to ingest spermatozoa from the lumen. The observation of spermiophagy after administration of $\alpha$-chlorhydrin suggested the possibility that the drug had altered or killed the spermatozoa and had thus made them vulnerable to phagocytosis. Such an interpretation would have been consistent with the concept that the tract has a capacity for selective resorption of dead or deteriorating spermatozoa (Roussel, Stallcup \& Austin, 1967). The observation of epithelial spermiophagy after careful ligation of an isolated loop of the ductus epididymidis without trauma to the ductuli efferentes or damage to the blood supply has made it apparent, however, that this is a consequence of obstruction per se and is not a cytotoxic effect of the drug. The nature of the stimulus that induces the epithelial cells of the ductuli to extend pseudopodia and engulf spermatozoa under these conditions when they rarely, if ever, do so normally is intriguing. Since spermatozoa survive for many days in the male reproductive tract in their normal fluid environment, it seems unlikely that spermiophagy beginning as early as $48 \mathrm{hr}$ after obstruction could be an expression of a mechanism for elimination of dead or defective spermatozoa. The normal ultrastructural appearance of the spermatozoa being ingested also contradicts this interpretation.

In the intact animals, the dilute suspension of spermatozoa coming from the rete testis traverses the efferent ductules rather rapidly. The ductuli have considerable capacity for reabsorption of water and, after obstruction, resorption of water from the seminal plasma may result in the rapid concentration of protein and various solutes in the lumen. The change in osmotic environment and the increase in hydrostatic pressure in the lumen may somehow stimulate the epithelial cells. On the other hand, this would not account for the reported, albeit infrequent, instances of spermiophagy in the cauda epididymidis which normally receives spermatozoa that are highly concentrated by resorption of fluid in more proximal segments of the tract.

The presence of macrophages in the lumen of the ductuli efferentes at longer intervals after administration of $\alpha$-chlorhydrin or ligation has a bearing upon an earlier interpretation of similar observations after vasectomy in men. Phadke (1964) suggested that the spermiophages in the lumen of the epididymis arose from the basal cells of the pseudostratified lining epithelium. Since this cell type is lacking in the simple epithelium of the ductuli efferentes, it seems clear that the intraluminal spermiophages observed in the present study were 
part of the ubiquitous mononuclear phagocyte system derived from the monocytes of the blood.

The possibility has been suggested that spermatozoa may be eliminated by their disintegration in the lumen (Young \& Simeone, 1930; Simeone \& Young, 1931). There has been some support for this in the observation that the incidence of dead and headless spermatozoa is greater in the corpus than in the cauda epididymidis, suggesting that the effete and dead spermatozoa are eliminated between these two segments (Glover, 1961). A mechanism adequate to account for extracellular intraluminal destruction of spermatozoa has yet to be demonstrated. Fluid collected from the ductuli efferentes of slaughtered rams is said to contain low levels of acid phosphatase ( $R$. Jones, unpublished observations cited in Moniem \& Glover, 1972). The source of this enzyme is not clear but it would seem to come from the testis. The epithelium of the ductuli (Hoffer, 1972) and of the epididymis is known to be rich in lysosomes (Friend \& Farquhar, 1967; Moniem \& Glover, 1972) but, despite suggestions to the contrary (Martan, 1969; Waldschmidt \& Karg, 1973), there is no conclusive evidence for the secretion of lysosomal enzymes into the lumen of the excurrent duct system. The acrosomes contain proteases and other hydrolytic enzymes (Allison \& Hartree, 1970) and phosphatase activity has been demonstrated in the protoplasmic droplet (Dott \& Dingle, 1968). It might be inferred, therefore, that the spermatozoa carry the seeds of their own destruction and that alteration of $\mathrm{pH}$ or osmolarity might cause disruption of membranes and release of these enzymes into the lumen of the tract. It seems questionable, however, whether this mechanism alone would result in concentrations of enzyme sufficient to dispose of such resistant structures as condensed nuclei and the dense outer fibres of sperm tails. On the other hand, after obstruction, the mobilization of macrophages and neutrophils and their intraluminal disintegration could conceivably release additional hydrolases and create physicochemical conditions more favourable to intraluminal digestion. The masses of dense homogeneous material observed after long periods in the ductuli efferentes proximal to an obstruction could be interpreted as accumulated products of intraluminal dissolution of spermatozoa. This interpretation would be more plausible, however, if the material observed in the lumen in electron micrographs was less amorphous and contained partly degraded sperm components. It has already been shown (see 'Results') that the fibrous sheath and outer coarse fibres were the most resistant components of the degenerating sperm tails to degradation inside the ductuli epithelial cells. The slow disposal of these fibres is not unexpected in view of their remarkable resistance to solubilization in vitro for biochemical analysis (Price, 1973; Baccetti, Pallini \& Burrini, 1973). Nonetheless, intraluminal extracellular dissolution, as well as phagocytosis probably plays a rôle in the removal of spermatozoa from the lumen of the epididymal duct, but the mechanism of extracellular dissolution is not completely understood at the present time.

The present study has demonstrated that high epididymal obstruction induces, within $48 \mathrm{hr}$, phagocytosis of spermatozoa by the epithelial cells of the rat ductuli efferentes. Invading macrophages and neutrophils become effective later. It leaves unexplained both the mechanism by which obstruc- 
tion stimulates the epithelium to this unusual behaviour, and the means by which macrophages and neutrophils, not normally present in the lumen in significant numbers, are attracted to it under these conditions. The question of intraluminal extracellular dissolution of spermatozoa also remains unsolved.

\section{ACKNOWLEDGMENTS}

This research was supported by grants from the Population Council, by U.S.P.H.S. Grant HD-04290 and Research Contract No. NIH-69-2017. One of us (A.P.H.) was the recipient of a Pharmaceutical Manufacturers Association Foundation Award and D.W.H. was the recipient of a U.S.P.H.S. Research Career Development Award.

\section{REFERENCES}

Alexander, N. J. (1972) Vasectomy: long-term effects in the rhesus monkey. F. Reprod. Fert. 31, 399406.

Alzison, A. G. \& Hartree, E. F. (1970) Lysosomal enzymes in the acrosome and their possible role in fertilization. J. Reprod. Fert. 21, 501-515.

Amann, R. P. \& Almourst, J. O. (1962) Reproductive capacity of dairy bulls. VI. Effect of unilateral vasectomy and ejaculation frequency on sperm reserves; aspects of epididymal physiology. 7. Reprod. Fert. 3, 260-268.

Austis, C. R. (1959) Entry of spermatozoa into the Fallopian-tube mucosa. Nature, Lond. 183, 908-909.

Austin, G. R. \& Bishop, M. W. H. (1959) Presence of spermatozoa in the uterine-tube mucosa of bats. F. Endocr. 18, viii-ix.

Baccietti, B., Pallini, V. \& Burrini, A. G. (1973) The accessory fibers of the sperm tail. I. Structure and chemical composition of bull "coarse fibers". F. submicrosc. Cytol. 5, 237-256.

Benort, J. (1926) Recherches anatomiques, cytologiques et histophysiologiques sur les voies excrétices du testicule, chez les Mammifères. Archs Anat. Histol. Embryol. 5, 173-412.

Burgos, M. H. (1964) Uptake of colloidal particles by cells of the caput epididymidis. Anat. Rec. 148, $517-525$.

Crabo, B., Gustafsson, B., Nicander, L. \& Rao, A. R. (1971) Subnormal testicular function in a bull concealed by phagocytosis of abnormal spermatozoa in the efferent ductules. F. Reprod. Fert. 26, 393-396.

Dotr, H. M. \& Dingle, J. T. (1968) Distribution of lysosomal enzymes in the spermatozoa and cytoplasmic droplets of bull and ram. Expl Cell Res. 52, 523-540.

FLICKINGER, C. J. (1972) Alterations in the fine structure of the rat epididymis after vasectomy. Anat. Rec. 173, 277-300.

FRIEND, D. S. \& FARQUHAR, M. G. (1967) Functions of coated vesicles during protein absorption in the rat vas deferens. F. Cell Biol. 35, 357-376.

Grover, T. D. (1961) Disintegrated spermatozoa from the epididymis. Nature, Lond. 190, 185-186.

GraNt, I. H. (1958) The passage of trypan blue through the epididymis and its uptake by this organ. Stud. Fert. 10, 95-101.

Hamiton, D. W. (1975) Structure and function of the epithelium lining the ductuli efferentes, ductus epididymis, and ductus deferens in the rat. In Handbook of Physiology. Endocrinology. Eds. E. B. Astwood and R. O. Greep. American Physiological Society, Bethesda, Maryland.

Horrer, A. P. (1972) The fine structure of the ductuli efferentes in mouse and rat. Anat. Rec. 172, 331332.

Horfer, A. P. \& Hamitron, D. W. (1974) Phagocytosis of sperm by the epithelial cells in ductuli efferentes of experimental rats. Anat. Rec. 178, 376-377.

Hofrer, A. P., Hamilton, D. W. \& FAwGEtT, D. W. (1973) The ultrastructural pathology of the rat epididymis after administration of $\alpha$-chlorhydrin (U-5897). I. Effects of a single high dose. Anat. Rec. 175, 203-230.

Hotstein, A. F. (1967) Spermiophagen im Nebenhoden des Menschen. Naturwissenschaften, 54, 98-99.

KoEfoed-Johnsen, H. H. (1964) Spermieproduktionen hos tyre. Udskillelsen af spermier med urinen ved forskellige saedopsamlingshyppigheder. (Sperm production in bulls. The excretion of sperm with the urine at different ejaculation frequencies.) Kgl. Vet.- og Landbohojskole, Aarsberetning, Inst. for Sterilitetsforskning, Copenhagen, pp. 23-27. 
Lino, B. F., Braden, A. W. H. \& Turndult, K. E. (1967) Fate of unejaculated spermatozoa. Nature, Lond. 213, 594-595.

Martan, J. (1969) Epididymal histochemistry and physiology. Biol. Reprod., Suppl. 1, 134-154.

Mason, K. E. \& Shaver, S. L. (1952) Some functions of the caput epididymidis. Ann. N.Y. Acad. Sci. 55, 585-593.

MONIEM, K. A. \& Glover, T. D. (1972) Comparative histochemical localization of lysosomal enzymes in mammalian epididymis. 7. Anat. 111, 437, Abstr.

Nicander, L. (1963) Resorption phenomena in the epididymis. Int. F. Fert. 8, 866, Abstr.

NiCANDER, L. (1965) An electron microscopical study of absorbing cells in the posterior caput epididymidis of rabbits. Z. Zellforsch. mikrosk. Anat. 66, 829-847.

Ossund, R. M. (1928) The physiology of the male reproductive system. F. Am. med. Ass. 90, 829-830.

Phadke, A. M. (1964) Fate of spermatozoa in cases of obstructive azoospermia and after ligation of vas deferens in man. F. Reprod. Fert. 7, 1-12.

Price, J. M. (1973) Biochemical and morphological studies of outer dense fibers of rat spermatozoa. J. Cell Biol. 59, 272A.

Reid, B. L. \& Cleland, K. W. (1957) The structure and function of the epididymis. I. The histology of the rat epididymis. Aust. F. Zool. 5, 223-246.

Roussez, J. D., Stallcup, O. T. \& Austin, C. R. (1967) Selective phagocytosis of spermatozoa in the epididymis of buils, rabbits, and monkeys. Fert. Steril. 18, 509-516.

SEDAR, A. W. (1966) Transport of exogenous peroxidase across the epithelium of the ductuli efferentes. 7. Cell Biol. 31, 102A.

Shaver, S. L. (1954) The role of stereocilia in removing India ink particles from the lumen of the rat epididymis. Anat. Rec. 119, 177-183.

Simeone, F. A. \& Young, W. G. (1931) A study of the function of the epididymis. IV. The fate of nonejaculated spermatozoa in the genital tract of the male guinea pig. F. exp. Biol. 8, 163-175.

Tingari, M. D. \& LAKE, P. E. (1972) Ultrastructural evidence for resorption of spermatozoa and testicular fluid in the excurrent ducts of the testis of the domestic fowl, Gallus domesticus. F. Reprod. Fert. 31, 373-381.

Vtrale-Calpe, R., Fawcett, D. W. \& Dym, M. (1973) The normal development of the blood testis barrier in the rat, and the effects of clomiphene and estrogen treatment. Anat. Rec. 176, 333-344.

WALDSGHMtDT, M. \& KARG, H. (1973) Review on metabolic and enzymic studies of spermatozoa from the ampullae ductus deferentiae of bulls. Adv. Biosci. 10, 169-180.

Wilhelm, S. F. \& Seligman, A. W. (1937) Spermatozoa in urine. Am. F. Surg. 35, 572-574.

Young, W. C. (1933) Die resorption in den Ductuli efferentes der Maus und ihre Bedeutung für das Problem der Unterbindung in Hoden-Nebenhoden System. Z. Zellforsch. mikrosk. Anat. 17, 729-759.

Young, W. C. \& Simeone, F. A. (1930) Development and fate of spermatozoa in the epididymis and vas deferens in the guinea pig. Proc. Soc. exp. Biol. Med. 27, 838-841. 